\title{
Desetletna deklica z akutno vročino, levkocitopenijo, trombocitopenijo in patološkimi jetrnimi encimi
}

\section{Ten-year-old girl with fever, leukocytopenia, thrombocytopenia and pathological liver function}

Nina Obolnar, Tatjana Avšič - Županc, Miroslav Petrovec, Maja Arnež

\section{Izvleček}

$\checkmark$ prispevku prikazujemo primer desetletne deklice $z$ vročino, trombocitopenijo, levkopenijo in patološkimi vrednostmi jetrnih encimov. Povzemamo stopenjsko obravnavo precej pogostega stanja in glavne diferencialnodiagnostične možnosti. Pri deklici smo ugotovili šesto otroško bolezen, ki je v njeni starosti neobičajna.

Ključne besede: otrok, vročina, levkocitopenija, trombocitopenija.

\begin{abstract}
We report the case of a ten-year-old girl with a fever, thrombocytopenia, leucocytopenia and pathological liver enzymes. We summarise a stepwise approach to this fairly common condition and the main options for the differential diagnosis. This girl was diagnosed with sixth disease, which is rather unusual for her age.
\end{abstract}

Key words: child, fever, leucocytopenia, thrombocytopenia. 


\section{Uvod}

Vročina s spremljajočimi spremembami v krvni sliki je klinični znak, s katerim se pogosto srečujemo $v$ urgentni ambulanti. Ker je posledica različnih bolezni, je pomembno hitro in pravilno diagnosticiranje, saj se zdravljenje lahko zelo razlikuje (1). Izsledki enomesečne raziskave pri odraslih bolnikih, ki so obiskali Nujno medicinsko pomoč v Ljubljani, kažejo, da ima nepravilnosti v krvni sliki 25,4 \% bolnikov (2). Bicitopenija je lahko posledica neposrednega zaviranja kostnega mozga s strani različnih povzročiteljev okužbe ter maligne ali revmatske bolezni. Nastane lahko tudi iatrogeno zaradi zdravil, kemoterapije ali radioterapije (1). $\checkmark$ omenjeni raziskavi so ugotovili, da je najbolj pogost vzrok trombocitopenije virusna okužba, medtem ko levkopenija ni le posledica virusne okužbe in jemanja zdravil, ampak lahko tudi nekaterih bakterijskih okužb (npr. brucela, rikecije, Salmonella typhi, razsejana tuberkuloza idr.). Pri bolnikih iz omenjene raziskave je bila bicitopenija pogosto tudi posledica krvne in revmatske bolezni $(2,3)$. V Sloveniji, ki je endemično področje za lymsko boreliozo, klopni meningoencefalitis in humano granulocitno anaplazmozo, moramo pomisliti tudi na bolezni, ki se prenašajo $z$ vbodom okuženega klopa (4). Pri otroku z vročino, levkopenijo in trombocitopenijo ne smemo pozabiti na življensko nevarno hemofagocitno limfohistiocitozo (HLH), redko krvno bolezen, za katero je značilen prekomeren vnetni odziv. Merila za postavitev diagnoze HLH prikazujemo v Tabeli $1(3,5)$.

$\checkmark$ prispevku prikazujemo desetletno deklico z vročino, trombocitopenijo, levkopenijo in patološkimi vrednostmi jetrnih encimov, pri kateri smo ugotovili šesto otroško bolezen $t$. i. exanthema subitum, ki je za njeno starost neobičajna. Potek bolezni je bil nezapleten. Podajamo diferencialnodiagnostične možnosti, na katere moramo pomisliti pri bolniku z opisanimi težavami v urgentni ambulanti.

\section{Prikaz primera}

Desetletno deklico so $v$ začetku meseca maja pripeljali $v$ urgentno ambulanto Klinike za infekcijske bolezni in vročinska stanja Univerzitetnega kliničnega centra v Ljubljani zaradi štiri dni trajajoče povišane telesne temperature do $40{ }^{\circ} \mathrm{C}$, slabega počutja in inapetence. Rednega zdravljenja ni prejemala. Mesec dni pred pregledom si je odstranila klopa, ki ga je dobila v domačem okolju. Neposredno po odstranitvi klopa je imela na mestu vboda rdečino, medtem ko kožne spremembe tipa erythema migrans ni opazila. Izbrani zdravnik je opravil hitri test brisa žrela na prisotnost piogenega streptokoka, ki je bil pozitiven, in hitri test na prisotnost virusa Epstein-Barr (EBV), ki je pokazal, da je okužbo s tem virusom prebolela $v$ preteklosti. $\vee$ krvni sliki je ugotovil levkopenijo $\left(2,1 \times 10^{9} / \mathrm{l}\right)$ in trombocitopenijo $\left(95 \times 10^{9} / \mathrm{l}\right)$ ter deklico napotil na našo kliniko $z$ napotno diagnozo streptokokni faringitis.

Ob pregledu je bila deklica neprizadeta in afebrilna. Nasičenost krvi s hemoglobinom na sobnem zraku je bila $99 \%$, srčni utrip 103/min, kapilarni povratek $<2 \mathrm{~s}$ in arterijski krvni tlak 130/86 mmHg. Meningealnih znakov ni imela. Koža in vidne sluznice so bile normalno prekrvljene in brez izpuščaja. Klinično ni imela znakov sepse. Krvavela ni. V kliničnem statusu smo ugotovili pordela nebna loka in drobno papulo nad popkom, kjer si je odstranilia klopa. Klinično ni izpolnjevala Centorjevih meril za diagnozo streptokokna angina. Povečanih jeter, vranice in perifernih bezgavk nismo tipali. Nad srcem in pljuči nismo ugotavljali odstopanj od normalnega stanja. Ponovili smo hematološke preiskave krvi ter opravili dodatne biokemijske in mikrobiološke preiskave krvi za opredelitev etiologije bolezni. Konentracija C-reaktivnega proteina (CRP) v krvi je bila povečana (77 mg/l), celokupno število levkocitov $v$ periferni krvi znižano $\left(2,1 \times 10^{9} / 1\right)$, prav tako število trombocitov $\left(98 \times 10^{9} / l\right)$. Rezultat rdeče krvne slike je bil normalen.
Ugotovili smo patološki hepatogram $z$ alkalno fosfatazo (AF) $6,43 \mu \mathrm{kat} / \mathrm{l}$, aspartat transaminazo (AST) 4,16 $\mu \mathrm{ka}$ $\mathrm{t} / \mathrm{l}$, alanin transaminazo (ALT) 3,53 $\mu \mathrm{ka}$ $\mathrm{t} / \mathrm{l}$, gama-glutamil transferazo $(\mathrm{\gamma}-\mathrm{GT})$ 4,86 $\mu \mathrm{kat} / \mathrm{l}$, laktatno dehidrogenazo (LDH) $10,31 \mu \mathrm{kat} / \mathrm{l}$ in celokupnim bilirubinom $51 \mu \mathrm{mol} / \mathrm{l}$ (direktni $38 \mu \mathrm{mol} / \mathrm{l}$ ).

Deklico smo zdravili ambulantno z delovnimi diagnozami vročina po vbodu klopa, levkopenija in trombocitopenija. Zaradi anamnestičnega podatka o vbodu klopa smo razmišljali o humani granulocitni anaplazmozi in prvi fazi klopnega meningoencefalitisa, glede na epidemiološke razmere pa tudi o mišji mrzlici in okužbi z enim od respiratornih virusov. Od mikrobioloških preiskav smo zato opravili bris nosnega žrela na prisotnost respiratornih virusov, poskus dokaza DNK bakterije Anaplasma phagocytophilum in RNK hantavirusov $v$ krvi $z$ verižno reakcijo $s$ polimerazo (angl. polymerase chain reaction, $P C R$ ) ter shranili vzorce krvi za morebitne dodatne mikrobiološke preiskave. Rezultat opravljenih preiskav je bil negativen (Tabela 2).

Čez dva dni je deklica prišla na kontrolni pregled. Mati je povedala, da že dva dni nima vročine, po koži telesa pa je opazila izpuščaj. Glede na potek bolezni smo pomislili na šesto otroško bolezen, glede na starost pa na peto otroško bolezen ali erythema infectiousum. Ob pregledu je imela deklica po koži telesa generaliziran makulopapulozni izpuščaj z nakazano rdečino lic, a brez značilnega izgleda »oklofutanih lic«, značilnega za peto otroško bolezen. $V$ ostalem je bil klinični status normalen.

V laboratorijskih izvidih sta bili še vedno prisotni levkopenija $3,5 \times 10^{9} / / \mathrm{s}$ prevlado normalnih limfocitov (47\%) in trombocitiopenija $95 \times 10^{9} / \mathrm{l}$. Koncentracija CRP se je znižala na $34 \mathrm{mg} / \mathrm{l}$, povišane aktivnosti serumskih jetrnih encimov pa so vztrajale (AF $8,21 \mu \mathrm{kat} / \mathrm{l}$, AST 2,51 $\mu \mathrm{kat} / \mathrm{l}$, ALT 3,41 $\mu \mathrm{kat} / \mathrm{l}$ in $\gamma-\mathrm{GT}$ $5,83 \mu \mathrm{kat} / \mathrm{l})$. Raven bilirubina in proteinogram sta bila normalna. 
Za potrditev diagnoze mora biti izpolnjenih 5 od 8 sledečih meril

vročina

splenomegalija

citopenija (prizadeti $\geq 2$ od 3 vrst krvnih celic):

- $\mathrm{Hb}<90 \mathrm{~g} / \mathrm{l}$ (pri dojenčkih, mlajših od 4 tednov $<100 \mathrm{~g} / \mathrm{l}$ )

- trombociti $<100 \times 10 \%$

- nevtrofilci $<1,0 \times 10 \%$

hipertrigliceridemija in/ali hipofibrinogenemija:

- trigliceridi $\geq 3,0 \mathrm{mmol} / \mathrm{l}$

- fibrinogen $\leq 1,5 \mathrm{~g} / \mathrm{l}$

hemofagocitoza v kostnem mozgu ob izključeni maligni bolezni

nizka ali odsotna aktivnost celic NK

hiperferitinemija $\geq 500 \mathrm{ng} / \mathrm{l}$

zvišana vrednost topnega CD25 (npr. topni receptor IL-2) $\geq 2,400 \mathrm{E} / \mathrm{ml}$

TABELA 1. MERILA ZA POSTAVITEV DIAGNOZE HEMOFAGOCITNA LIMFOHISTIOCITOZA $(3,6)$.

TABLE 1. CRITERIA FOR THE DIAGNOSIS OF HAEMOPHAGOCYTIC LYMPHOHISTIOCYTOSIS $(3,6)$

\begin{tabular}{|c|c|}
\hline Preiskava & Izvid \\
\hline $\begin{array}{l}\text { ugotavljanje specifičnih protiteles IgG proti bakteriji Anaplasma } \\
\text { phagocytophilum }\end{array}$ & negativno \\
\hline dokazovanje DNK bakterije Anaplasma phagocytophilum (PCR) & negativno \\
\hline dokazovanje RNK hantavirusov (PCR) & negativno \\
\hline $\begin{array}{l}\text { ugotavljanje specifičnih protiteles proti virusu klopnega } \\
\text { meningoencefalitisa }\end{array}$ & negativno \\
\hline dokazovanje RNK virusa klopnega meningoencefalitisa (PCR) & negativno \\
\hline $\begin{array}{l}\text { respiratorni virusi, razširjen panel (influenca } A \text {, influenca } B \text {, } \\
\text { RSV, adenovirus, bokavirus, koronavirus, metapnevmovirus, } \\
\text { parainfluenca, rinovirusi, enterovirusi, paraehovirusi) }\end{array}$ & negativno \\
\hline hepatitis A: protitelesa anti-HAV IgG, anti-HAV IgM & negativno \\
\hline hepatitis B & $\begin{array}{l}\text { antigeni HbsAg nereaktiven } \\
\text { anti-HBc IgM negativno } \\
\text { protitelesa anti-HBs pozitivno } \\
(>1000 \mathrm{UI} / \mathrm{I})\end{array}$ \\
\hline hepatitis C: presejalni test & nereaktiven \\
\hline hepatitis E: anti HEV IgG, anti HEV IgM & negativno \\
\hline parvovirus B19: protitelesa IgG, IgM & negativno \\
\hline parvovirus B19 DNA (PCR kvalitativno) & negativno \\
\hline citomegalovirus (CMV) - protitelesa IgG, IgM & negativno \\
\hline HHV-6 DNK (PCR, kvalitativno) & pozitivno \\
\hline HHV-6: protitelesa IgM, IgG & $\begin{array}{l}\text { IgM pozitivno (titer } 1: 20 \text { ) } \\
\text { IgG pozitivno (titer } 1: 80 \text { ) }\end{array}$ \\
\hline HHV-6: protitelesa IgM, IgG (po enem mesecu) & $\begin{array}{l}\text { IgM negativno } \\
\text { IgG reaktivno (titer } 1: 10 \text { ) }\end{array}$ \\
\hline
\end{tabular}

TABELA 2. MIKROBIOLOŠKE PREISKAVE KRVI PRI DESETLETNI DEKLICI Z AKUTNO VROČINO, LEVKOPENIJO, TROMBOCITOPENIJO IN PATOLOŠKIMI VREDNOSTMI JETRNIH ENCIMOV.

TABLE 2. MICROBIOLOGICAL BLOOD TESTS IN A 10-YEAR-OLD GIRL WITH ACUTE FEVER, LEUCOPENIA, THROMBOCYTOPENIA AND PATHOLOGICAL LIVER ENZYMES.

Opombe: Protitelesa proti hepatitisu B (anti HBs) so odraz uspešnega cepljenja.
Z dodatnimi mikrobiološkimi preiskavami smo pri deklici izključili okužbo z virusom klopnega meningoencefalitisa, parvovirusom B19 in virusne hepatitise, potrdili pa smo akutno okužbo s humanim herpesvirusom tipa 6 (HHV6), ki je povzročitelj šeste otroške bolezni (Tabela 2).

Ob kontrolnem pregledu čez en mesec je bila deklica klinično zdrava. Rezultati hematoloških in biokemijskih preiskav krvi so bili v mejah normalnih vrednosti. Ponovili smo serološke preiskave na HHV-6, ki so potrdile akutno okužbo. Deklica je prebolela šesto otroško bolezen exanthema subitum ali roseola infantum, ki je potekala brez zapletov in je značilna predvsem za dojenčke in majhne otroke.

\section{Razpravljanje}

Desetletna deklica z levkopenijo in trombocitopenijo je bila zaradi pozitivnega brisa žrela na piogeni streptokok napotena $v$ urgentno ambulanto naše klinike $z$ napotno diagnozo streptokokni faringitis. Ob pregledu ni izpolnjevala Centorjevih meril za diagnozo. Imela je vročino in ni kašljala, ni pa imela vnetih in obloženih nebnic ter bolečih povečanih vratnih bezgavk. Izpolnjevala je zgolj dve od štirih meril za diagnozo streptokokna angina, zato odvzem brisa žrela na piogeni streptokok ni bil upravičen. Pri deklici pozitiven rezultat pomeni klicenoštvo piogenega streptokoka v žrelu.

Slovenija je endemično področje za zoonoze, ki jih prenašajo klopi vrste Ixodes ricinus in se lahko kažejo s klinično sliko bicitopenije in $z$ vročino. To so okužbe, povzročene $z$ virusom klopnega meningoencefalitisa (klopni meningoencefalitis), bakterijo Anaplasma phagocytophilum (humana granulocitna anaplazmoza) in bakterijo Borrelia burgdorferi sensu lato (lymska borelioza) $(6,7)$. Za bolnike s klopnim meningoencefalitisom nimamo na voljo specifičnega zdravljenja, bolnike $z$ lymsko boreliozo in humano 
granulocitno anaplazmozo pa lahko uspešno pozdravimo s priporočenimi protimikrobnimi zdravili (4). V obdobju, ko smo obravnavali našo bolnico, smo ugotavljali tudi porast okužbe s hantavirusi, ki jih prenašajo miši in povzročajo hemoragično vročico, t. i. mišjo mrzlico. S podobno klinično sliko se kažejo tudi druge virusne bolezni, npr. influenca $A$ in influenca $B$, parainfluenca ter okužba $z$ respiratornim sincicijskim virusom, rinovirusi, adenovirusi, enterovirusi, metapnevmovirusi in bokavirusi. Vročino z bicitopenijo povzročata tudi parvovirus B19 in HHV-6, ki sta povzročitelja pete in šeste otroške bolezni, za kateri je značilen kožni izpuščaj (6).

Pri naši bolnici so anamnestični podatki o vbodu klopa govorili v prid bolezni, ki se prenaša z vbodom okuženega klopa, a deklica ni imela klinične slike, značilne za lymsko boreliozo, z mikrobiološkimi preiskavami pa smo izključili klopni meningoencefalitis in humano granulocitno anaplazmozo (Tabela 2). Klopni meningoencefalitis ima tipičen dvofazni potek. Za prvo fazo bolezni je značilna viremija, ki jo lahko spremljajo vročina, levkopenija in trombocitopenija. V tej fazi imajo bolniki patološke vrednosti jetrnih encimov in včasih tudi klinično jasen miozitis. V drugi fazi bolezni se pojavijo simptomi in znaki prizadetosti osrednjega živčevja, a ni nujno, da bolezen napreduje v drugo fazo (6). Inkubacijska doba (čas od vboda klopa do pojava prvih bolezenskih znakov) pri naši bolnici bi se ujemala s klopnim meningoencefalitisom, a je predolga za okužbo z $A$. phagocytophilum, pri kateri je povprečna inkubacijska doba sedem dni (4). Pozneje v poteku bolezni se je pri naši bolnici pojavil generaliziran kožni izpuščaj. Omenjene bolezni običajno nimajo generaliziranega kožnega izpuščaja, ki je glavni klinični znak okužbe s HHV-6, a v literaturi zasledimo tudi opise okužbe s HHV-6, pri katerih izpuščaja ni (8).

HHV-6 je herpesvirus in povzročitelj šeste otroške bolezni. Pojavlja se po celem svetu. Raziskave so poka- zale, da se v Evropi, Združenih državah Amerike in na Japonskem večina otrok z virusom okuži do 2 . leta starosti, medtem ko je razširjenost (prevalenca) okužbe v subsaharski Afriki pri otrocih do 2. leta samo $1 \%$ (8). Virus se prenaša oralno ter potuje $v$ žleze slinavke in limfno tkivo, kjer se pomnožuje v celicah $T(6,8)$. Po vdoru v kri (viremija) se začne bolezen, za katero je značilna visoka vročina, ki traja 1-5 dni. Po koncu viremije se telesna temperatura nenadoma zniža na normalne vrednosti, po koži telesa, pretežno po trupu, pa se pojavi makulopapulozen izpuščaj. Exanthema subitum se najpogosteje pojavi pri otrocih, mlajših od dveh let. Pri starejših otrocih in mladostnikih jo ugotovimo pri $17 \%$, zato pri naši bolnici nismo takoj pomislili na šesto otroško bolezen. Bolezen diagnosticiramo klinično in serološko, tj. z dokazom serokonverzije ali štirikratnim porastom specifičnih protiteles IgM in IgG HHV-6 v parnih serumih bolnika. V nejasnih primerih, zlasti če okužba s HHV-6 poteka brez značilnega kožnega izpuščaja, jo lahko dokažemo tudi z dokazom virusne DNK v bolnikovi krvi z metodo PCR. Exanthema subitum lahko poteka s trombocitopenijo, levkopenijo in nevtropenijo, kar smo ugotovili tudi pri naši bolnici. Zdravili smo jo simptomatsko, saj je bolezen potekala brez zapletov. Če HHV-6 povzroči encefalitis, svetujejo zdravljenje z virostatiki, kot sta ganciklovir ali foskarnet (6).

Pri naši bolnici smo po pojavu kožnega izpuščaja glede na starost najprej pomislili na peto otroško bolezen, ki jo povzroča parvovirus B19, a deklica na obrazu ni imela izpuščaja, značilnega za peto otroško bolezen. Erythema infectiosum je bolezen, ki se v prodromalnem obdobju lahko kaže z vročino, levkopenijo in trombocitopenijo ter običajno mine sama od sebe, brez zdravljenja. Pri bolnikih s kronično hemolitično anemijo lahko povzroči aplastično krizo, zato bolnik potrebuje transfuzijo rdečih krvničk. Predvsem pri odraslih se lahko v poteku bolezni pojavi artritis, pri imunsko oslabelih osebah pa kronična viremija, ki zahteva zdravljenje $z$ intravenskimi imunoglobulini. Parvovirus B19 je teratogen. Pri akutno okuženi nosečnici lahko povzroči smrt ploda (9). Pri otrocih opisujejo tudi primere miokarditisa. Parvovirus B19 se rad veže na celice srčne mišice in povzroči imunsko posredovane okvare miokarda s hipoksično-ishemičnimi okvarami (10). V primerjavi s šesto otroško boleznijo, ki je značilna za dojenčke in majhne otroke, se peta otroška bolezen pojavlja pretežno pri šolskih otrocih. Prisotnost specifičnih protiteles med puberteto je $50 \%$ in nato do odraslosti narašča (9). Klinična slika je lahko podobna (11).

Pri bolnikih z akutno vročino in patološko krvno sliko moramo pomisliti tudi na krvne bolezni. $Z$ raziskavo na otroškem hematološkem oddelku v Indiji so ugotovili bicitopenijo pri $40 \%$ bolnikov in pancitopenijo pri $17,7 \%$ bolnikov, ki so bili napoteni na preiskavo kostnega mozga. Pri otrocih z bicitopenijo v $16 \%$ niso ugotavljali maligne bolezni, temveč idiopatsko trombocitopenično purpuro, anemijo ali okužbo. Pri otrocih s pancitopenijo so pri $44,6 \%$ odkrili nemaligno bolezen, pri $21,1 \%$ maligno bolezen, pri $20,6 \%$ iatrogeno sproženo pancitopenijo in pri $13,7 \%$ nespecifičen izvid. V obeh skupinah je bilo najpogostejša maligna bolezen akutna levkemija (1). Tudi na naši kliniki smo v sezoni gripe obravnavali 19-mesečno deklico $z$ akutno vročino, levkopenijo, trombocitopenijo in izrazito patološkim hepatogramom, pri kateri so pozneje diagnosticirali HLH (Tabela 1).

\section{Zaključek}

V prispevku smo prikazali primer desetletne deklice z akutno vročino, levkopenijo, trombocitopenijo in patološkimi vrednostmi jetrnih encimov, ki je prebolela šesto otroško bolezen. V diferencialni diagnozi akutne vročine $z$ levkopenijo in trombocitopenijo moramo v prvi vrsti pomisliti na okuž- 
be, ki zahtevajo specifično zdravljenje, ne smemo pa pozabiti na krvne ali revmatske bolezni, ki lahko ogrozijo otrokovo življenje.

\section{Literatura:}

1. Naseem S, Varma N, Das R, Ahluwalia J, Singh Sachdeva MU, Marwaha RK. Pediatric patients with bicytopenia/pancytopenia: Review of etiologies and clinico-hematological profile at a tertiary center. Indian J Pathol Microbiol 2011; 54: $75-80$

2. Cvejić Vidali G, Zver S, Podgornik H. Pregled najpogostejših nepravilnosti v izvidu krvne slike $v$ urgentnih ambulantah in prepoznava urgentnih stanj. Zdrav Vestn 2015; 84: 591-8.

3. Henter JI, Horne AC, Arico M, Egeler RM, Filipovich AH, Imashuku S et al. HLH-2004: diagnostic and therapeutic guidelines for hemophagocytic lymphohistiocytosis. Pediatr Blood Cancer 2007; 48: 124-31.

4. Arnež M. Bolezni, ki jih prenašajo klopi. 5. Bedjaničev simpozij. Maribor: Splošna bolnišnica 2005: 53-66.

5. Ishii E. Hemophagocytic lymphohistiocytosis in children: pathogenesis and treatment. Front Pediatr 2016; 4: 47.

6. Arnež M, Avšič-Županc T, Uršič T, Petrovec M. Human herpesvirus 6 infection presenting as an acute febrile illness associated with thrombocytopenia and leukopenia. Case Rep Pediatr 2016; 2483183.

7. Arnež M, Avšič-Županc T, Ružić-Sabljić E. Acute myositis associated with the initial phase of tick-borne encephalitis. J Clin Virol 2011; 51(4): 276-8.

8. Pantry NS, Medveczky PG. Latency, integration, and reactivation of human herpesvirus- 6 . viruses 2017; 9(7): 194.

9. Sim JY, Chang LY, Chen JM, Lee PI, Huang LM, Lu CY. Human parvovirus B19 infection in patients with or without underlying diseases. $J$ Microbiol Immunol Infect 2019; 18: 30222-6.

10. Izquierdo-Blasco J, Salcedo Allende MT, Codina Grau MG, Gran F, Martínez Sáez E, Balcells J. Parvovirus B19 Myocarditis: looking beyond the heart. Pediatr Dev Pathol 2019; 23: 1093526619865641.

11. Allmon A, Deane K, Martin KL. Common skin rashes in children. Am Fam Physician 2015; 1: 92(3): 211-6.
Nika Obolnar, dr. med.

\section{(kontaktna oseba / contact person)}

Klinika za infekcijske bolezni in vročinska stanja, Univerzitetni klinični center Ljubljana

Japljeva 2, 1000 Ljubljana, Ljubljana,

Slovenija

e-naslov: nika.obolnar@gmail.com

akad. prof. dr. Tatjana Avšič - Županc, dipl. univ. biol.

Inštitut za mikrobiologijo in imunologijo, Medicinska fakulteta, Univerza v Ljubljani, Ljubljana, Slovenija

izr. prof. dr. Miroslav Petrovec, dr. med. Inštitut za mikrobiologijo in imunologijo, Medicinska fakulteta, Univerza v Ljubljani, Ljubljana, Slovenija

izr. prof. dr. Maja Arnež, dr. med. Katedra za infekcijske bolezni in epidemiologijo, Medicinska fakulteta, Univerza v Ljubljani, Ljubljana, Slovenija

prispelo / received: 14. 8. 2019

sprejeto / accepted: 20. 10. 2019

Obolnar N, Avšič - Županc T, Petrovec M, Arnež M. Desetletna deklica z akutno vročino, levkocitopenijo, trombocitopenijo in patološkimi jetrnimi encimi. Slov Pediatr 2020; 27(1): 15-19. https://doi.org/10.38031/ slovpediatr-2020-1-03. 